\title{
The temperature of storage of a batch of wheat distillers dried grains with solubles samples on their nutritive value for broilers
}

by Whiting, I., Pirgozliev, V., Rose, S.P., Karadas, F., Mirza, M.W. and Sharper, A.

Copyright, Publisher and Additional Information: This is the author accepted manuscript. The final published version (version of record) is available online via Taylor \& Francis

Please refer to any applicable terms of use of the publisher.

DOI: $\underline{\text { http://dx.doi.org/10.1080/00071668.2017.1380297 }}$ 
1 The temperature of storage of a batch of wheat distillers dried grains with solubles 2 samples on their nutritive value for broilers

3

4 I. Whiting ${ }^{1}$, V. PIRGOZLIEV ${ }^{1 *}$, S. P. ROSE ${ }^{1}$, F. KARADAS ${ }^{2}$, M.W. MIRZA ${ }^{1}$, A. $5 \quad$ SHARPE $^{1}$

$7 \quad{ }^{1}$ The National Institute of Poultry Husbandry, Harper Adams University, Shropshire, TF10 $8 \quad 8 \mathrm{NB}, \mathrm{UK}$

$9 \quad{ }^{2}$ Department of Animal Science, Yuzuncu Yil University, Van, Turkey

10 *Correspondence: vpirgozliev@harper-adams.ac.uk

12 Short title: Storage of DDGS for broilers 
14 ABSTRACT 1. A batch of wheat distillers dried grains with solubles (DDGS) was obtained 15 immediately after production and was separated into 5 equal parts and placed in woven 16 polypropylene sacks. The samples were stored under five different temperature conditions for 17 one year as follows: kept at a constant $-20^{\circ} \mathrm{C}$; kept at $-20^{\circ} \mathrm{C}$ for $24 \mathrm{~h}$ period and after that kept 18 at a constant $+4^{\circ} \mathrm{C}$; kept at a constant $+4^{\circ} \mathrm{C}$ only; kept at a constant $+15^{\circ} \mathrm{C}$; stored at ambient 19 temperature (range of weekly mean temperatures was from +4 to $+22^{\circ} \mathrm{C}$ ).

20 2. Each of the 5 wheat DDGS samples was included $(200 \mathrm{~g} / \mathrm{kg})$ in a nutritionally complete 21 diet and fed to broiler chickens from 7 to $21 \mathrm{~d}$ of age. The chemical composition of the 22 DDGS samples was determined at the beginning and at the end of the one year storage 23 period.

24 3. The nitrogen corrected apparent metabolisable energy (AMEn) and the nutrient availability 25 of each sample was measured using a total collection technique. The growth performance of 26 birds was also determined.

27 4. The DDGS samples kept at a constant $-20^{\circ} \mathrm{C}$ had higher dry matter, lower oxidation value 28 and lower antioxidant contents. The DDGS sample that was stored at ambient temperatures had a higher $(\mathrm{P}<005)$ AMEn than the rest of the DDGS samples.

30 5. The results of this experiment have shown that there can be changes in the AMEn of wheat 31 DDGS during storage at ambient temperatures. In general, there were no serious effects of 32 storage of DDGS on its feeding value to broiler chickens.

33 Key words: storage, wheat DDGS, broilers, metabolisable energy

\section{INTRODUCTION}

Wheat distillers dried grains with solubles (DDGS), by-product of bioethanol production, is rich in fat and protein and is used in poultry diet formulations (Whiting et al., 2016). Differences in seasonal demand results in some batches of DDGS being stored for long periods at ambient temperatures before they are incorporated in poultry diets. DDGS have a

41 relatively high content of unsaturated fatty acids so there is a potential that the batch may 42 deteriorate during the storage. Lipid oxidation has been implicated as a primary factor in the 43 deterioration in distiller's grains and brewer's spent grain products (Rasco, 1988). However, 
44 research assessing the effect of storage on feeding value of wheat DDGS for poultry is 45 lacking.

46 The aim of the study was to investigate the effects of five different storage temperature 47 regimens on $\mathrm{N}$-corrected dietary apparent metabolisable energy (AMEn), total tract nutrient 48 retention coefficients, and growth performance when fed to chickens (from 7 to $21 \mathrm{~d}$ of age).

\section{MATERIALS AND METHODS}

\section{Storage of DDGS samples}

The wheat DDGS sample used in this experiment was obtained directly from the manufacturer (Ensus UK Limited, Yarm, UK) immediately after production and was separated into 5 equal parts and placed in woven polypropylene sacks. The sacs held approximately $25 \mathrm{~kg}$ and were not stacked, so there was little compaction. The samples were stored under five different temperature conditions for approximately one year. The storage conditions were as follows: kept at a constant $-20^{\circ} \mathrm{C}$; kept at $-20^{\circ} \mathrm{C}$ for $24 \mathrm{~h}$ period and after that kept at a constant $+4^{\circ} \mathrm{C}$; kept at a constant $+4^{\circ} \mathrm{C}$ only; kept at a constant $+15^{\circ} \mathrm{C}$; stored at ambient temperature (range of weekly mean temperatures was from +4 to $+22^{\circ} \mathrm{C}$ ). The $-20^{\circ} \mathrm{C}$ for $24 \mathrm{~h}$ period, followed by $+4^{\circ} \mathrm{C}$ was included to evaluate the possibility that freezing alone could affect the nutrient availability of DDGS. The ambient temperature changes during this period were measured with a digital data logger (Electronic Temperature Instruments Ltd, Worthing, UK) installed in one of the ambient stored bags. The ambient stored DDGS sample did not experience any freezing temperatures during the storage (Figure 1). The DDGS samples were visually inspected at the end of storage and all appeared free from fungal contamination.

\section{Husbandry and sample collection}

Nutrient availability and growth performance were examined in a broiler chicken experiment from 7 to $21 \mathrm{~d}$ age. Each of the five DDGS samples were incorporated into a nutritionally complete diet in meal form at $200 \mathrm{~g} / \mathrm{kg}$ (800 $\mathrm{g}$ of the basal feed $+200 \mathrm{~g}$ of each DDGS sample) (Table 1). The nutrient specification of the diets met the breeder's recommendation (Aviagen Ltd.). A sixth dietary treatment was also fed that was the basal feed only. Male

77 Ross 308 broiler chickens were obtained from a commercial hatchery at day old and were 
78 placed in a single floor pen and fed on a proprietary broiler starter feed until $5 \mathrm{~d}$ of age. Then

792 birds were randomly allocated to one of 60 pens ( $\mathrm{n}=120$ birds in total) with $0.16 \mathrm{~m}^{2}$ solid

80 floor area to accustom them to a pen environment but fed then proprietary feed until $7 \mathrm{~d}$ of

81 age. On the first day of the experimental feeding period the chicks were weighed and the

82 experimental diets were randomly allocated to the pens. Access to the feed and the water was

83 ad libitum. There were 10 replicates for each diet. The temperature was $30^{\circ} \mathrm{C}$ at $7 \mathrm{~d}$ and was

84 gradually reduced to $20^{\circ} \mathrm{C}$ at the end of the $14 \mathrm{~d}$ feeding period $(21 \mathrm{~d}$ age $)$. A standard

85 lighting program for broilers was used, decreasing from 23:1 h (light:dark) from $1 \mathrm{~d}$ old to

$86 \quad 18: 6 \mathrm{~h}$ at $7 \mathrm{~d}$ of age, which was maintained until the end of the study.

87 At $17 \mathrm{~d}$ of age, the solid floor of each pen was replaced with a wire mesh floor, and the total 88 droppings were collected for four days until the end of the study. This change did not have an 89 effect on bird behaviour and daily feed intakes (FI). Feed intake for the same period was 90 recorded for the determination of dietary AMEn and total tract nutrient retention coefficients.

91 The total feeding period was $14 \mathrm{~d}$. All birds were weighed at the end of the study, and the 92 weight gain (WG) and feed conversion efficiency (FCE) were determined. The droppings 93 (egesta and excreta with visible feather, skin and regurgitated feed removed) were collected 94 for the last $96 \mathrm{~h}$ of the feeding period (collected every $24 \mathrm{~h}$ to avoid fermentation losses) and 95 the excreta samples were dried at $60^{\circ} \mathrm{C}$.

96 On the last day of the experiment, at $21 \mathrm{~d}$ old, one bird from each pen was selected at random 97 and killed by cervical dislocation. The liver of each bird was collected and stored at $-70^{\circ} \mathrm{C}$ 98 for antioxidant status analysis.

99 The Animal Experimental Committee of Harper Adams University approved all procedures.

\section{Chemical Analysis}

103 Dry droppings samples were weighed and milled to pass through a $0.75-\mathrm{mm}$ mesh. Gross 104 energy concentrations of the control feed, DDGS and droppings were measured using an 105 adiabatic bomb calorimeter (Model: 1261 Isoperibol Bomb Calorimeter, Parr Instrument 106 Company, Moline, IL, USA). Nitrogen was determined using a Leco nitrogen analyser (Leco 107 FP-528, Leco Corporation, St Joseph, MI, USA) according to AOAC method 968.06 (AOAC, 108 2000). Ether extract was determined according to AOAC methods 920.39 and 942.05, 109 respectively (AOAC, 2000). The colour score of the stored DDGS samples was carried out 110 using a Chroma Meter CR-400 from Konica Minolta (Sunderland, UK) to determine 111 luminance and chromaticity scores using CIELAB scoring. The peroxide values (PV) in the 
112 stored DDGS samples were determined according to AOAC method 965.33, by dissolving

113 the oil sample in a solvent and potassium iodide and then titrating with sodium thiosulfate

114 and using starch as an indicator (AOAC, 2000). The PV reveals the current level of oxidative

115 rancidity, measured as milli equivalents of peroxide per kilogram (meq $/ \mathrm{kg}$ ).

116 Non-starch polysaccharides (NSP) and total starch (TS) contents in the DDGS samples were

117 determined following the methods of Englyst (1994) and Englyst (2000), respectively.

118 The GE, DM, nitrogen and fat of each dried droppings sample and the experimental diets

119 were determined as described for the wheat samples. The AMEn of the diets was calculated 120 as described by Hill and Anderson (1958). The coefficients of total tract nutrient retention

121 were determined as the difference between intake and voiding of the nutrient, divided by their 122 respective intake.

123 The concentration of antioxidants, including total vitamin E, vitamin A and coenzyme $\mathrm{Q}_{10}$ in

124 DDGS samples and liver was determined using an HPLC system as previously described

125 (Surai et al., 2001; Karadas et al., 2009).

126

127 Statistical procedure

129 The observational unit was the cage with two birds. Statistical analyses were performed using 130 the GenStat statistical software package (GenStat 17 release 3.22 for Windows; IACR, 131 Rothamstead, Hertfordshire, UK). The AMEn and the nutrient retention coefficients of all 132 diets, including the basal diet and diets including DDGS samples stored under different 133 conditions were determined. Then the AMEn and the nutrient retention coefficients of the 134 DDGS samples were obtained using the substitution method (Finney, 1978) using the data 135 from the basal only diet. The results of all DDGS samples were statistically compared using a 136 randomised block analysis of variance. Duncan's multiple range test was used to determine 137 significant differences between DDGS treatment groups. In all instances, differences were 138 reported as significant at $P \leq 0.05$.

\section{RESULTS}

142 There were differences in dry matter contents of the stored wheat DDGS samples: The 143 sample stored at ambient temperature had the lowest dry matter content of $819 \mathrm{~g} / \mathrm{kg}$, and the 144 sample stored at $-20^{\circ} \mathrm{C}$ had the highest dry matter content of $883 \mathrm{~g} / \mathrm{kg}$, respectively (Table 2). 145 The average colour score of the stored DDGS samples was 42.6 , varying from 40.0 for the 
sample stored at ambient temperature to 45.1 for the sample stored at a constant $+4^{\circ} \mathrm{C}$. The

147 DDGS sample stored at $-20^{\circ} \mathrm{C}$ had a peroxide value of $0.0 \mathrm{mEq} / \mathrm{kg}$, as there were few 148 differences in the peroxide values of the rest of the samples and the average was 17.7

$149 \mathrm{mEq} / \mathrm{kg}$. The mean total vitamin A, vitamin E and coenzyme $\mathrm{Q}_{10}$ concentrations (presented as $150 \mu \mathrm{g} / \mathrm{g} \mathrm{DM})$, of stored wheat DDGS samples were 0.0718, 37.3, and $2.846(\mu \mathrm{g})$, respectively.

151 For vitamin $\mathrm{E}$ and coenzyme $\mathrm{Q}_{10}$, the sample stored at $-20^{\circ} \mathrm{C}$ had the lowest contents, and the 152 sample stored at constant $+15^{\circ} \mathrm{C}$ had the highest contents, respectively (Table 2).

153 The starch content of DDGS samples stored at ambient and $+15{ }^{\circ} \mathrm{C}$ was lower compared to 154 those stored at $-20^{\circ} \mathrm{C}$ and $+4^{\circ} \mathrm{C}$. Interestingly, the starch content of the DDGS sample stored 155 at changeable $\left(-20^{\circ} \mathrm{C}\right.$ for $24 \mathrm{~h}$ and after that constant $\left.+4^{\circ} \mathrm{C}\right)$ temperature was intermediate 156 (Table 2).

157 Birds remained healthy throughout the study period and there were no mortalities. Results on 158 bird growth performance, energy and retention coefficients are summarised on Table 3. There 159 were no differences $(\mathrm{P}>0.05)$ in FI, WG, FCE, liver weight and retention coefficients. The 160 growth performance of the birds was somewhat lower than the breeder's standards (Aviagen 161 Ltd, Edinburgh, UK) but the diets were fed in mash form. The AMEn of DDGS samples 162 stored at ambient temperature did not differ $(\mathrm{P}>0.05)$ from those stored at changeable $\left(-20^{\circ} \mathrm{C}\right.$ 163 for $24 \mathrm{~h}$ and after that constant $\left.+4^{\circ} \mathrm{C}\right)$ temperature, but was higher $(\mathrm{P}<0.05)$ compared to the 164 rest of the DDGS samples.

165 There were no differences $(\mathrm{P}>0.05)$ between hepatic antioxidant contents of broilers fed 166 differently stored DDGS samples (Table 4).

170 The study evaluated the effect of storage of one batch of wheat DDGS on dietary AMEn, 171 nutrient utilisation and growth performance of broilers. The proximate nutrient and GE 172 contents of the experimental wheat DDGS sample was similar to published reports 173 (Bolarinwa and Adeola, 2012; Whiting et al., 2016) although there is large variability 174 between different DDGS batches. The colour score of the wheat DDGS samples was in the 175 expected range (Cozanett et al., 2011) and did not indicate major changes due to storage 176 temperatures. Differences in nutrient retention coefficients was similar to those reported by 177 Whiting et al. (2016) when broilers were fed diets containing $150 \mathrm{~g} / \mathrm{kg}$ wheat DDGS. The 178 starch content of the DDGS samples was expectedly low because most available starch would 
be removed during distillation. The small reduction in total amounts in the $+15^{\circ} \mathrm{C}$ and the ambient temperature stored samples was unexpected but probably not nutritionally important. The original hypothesis of this experiment was that high storage temperatures could negatively affect the nutritional value of DDGS batches. Differences in seasonal demand for

183 DDGS can result in batches being stored for variable lengths of time. The results of this 184 experiment indicated that there was no evidence of a detrimental effect of storage and, in fact, 185 storage at ambient temperature gave an improved nutrient availability. There was no effect on 186 growth performance, but the experimental diets had a high nutrient specification so small 187 differences in nutrient availability were unlikely to give statistically significant differences in 188 growth performance.

189 Fats are susceptible to breakdown by oxidation to form peroxides, which are unstable compounds, and can become rancid. Apart of the DDGS sample stored at $-20^{\circ} \mathrm{C}$, the rest of the samples had 17.7 average PV value that was similar to those reported for stored rice bran

192 (Atapattu et al., 2013). In general fresh oils have a peroxide values well below $10 \mathrm{mEq} / \mathrm{Kg}$ 193 while peroxide values in the $30-40 \mathrm{mEq} / \mathrm{Kg}$ range are generally associated with a rancid taste.

194 Although the oxidation of oils is influenced by many factors, the storage temperature and 195 light are two of the main factors that influence the rate of autoxidation of feed (Berger, 1994).

196 All samples were stored in dark. The relatively small differences between the PV in DDGS 197 samples suggest that there were no large changes in the oxidative rancidity of the fat under different temperature storage conditions. The moisture in the DDGS samples were also low suggesting that there would have been little microbial activity causing hydrolytic fat degradation (Allison \& Treseder, 2008). The lack of response to feed intake and weight gain to different DDGS samples suggest no changes in dietary palatability. The lack of differences in hepatic antioxidant content and the good health of the birds also suggests that there was no production of harmful toxic products during DDGS storage.

204 There was some variation in vitamin E and A contents in the DDGS samples, as those stored 205 at constant positive temperatures had higher values. However, this variation was small relative to the amounts of these vitamins that would have been supplied in the vitamin and mineral premix. The hepatic antioxidants content was in agreement with previous research and did indicate good health of the birds (Karadas et al., 2014).

209 The DDGS sample that was stored at ambient temperatures had a higher AMEn than the rest 210 of the DDGS samples. Research on wheat storage also showed that wheat stored at ambient 211 temperature had a greater metabolisable energy than those stored at constant $-20^{\circ} \mathrm{C}$ 212 (Pirgozliev et al., 2006). Similar effects have been observed in storage experiments with 
213 whole grain wheat (Choct et al., 1995; Choct and Hughes, 1997), showing that the

214 metabolisable energy of stored wheat is affected by changes that occur during ambient

215 storage. Interestingly, the AMEn of the ambient temperature stored DDGS was higher that

216 the sample stored at constant $15^{\circ} \mathrm{C}$. The overall ambient temperature for the storage was

$21712.6^{\circ} \mathrm{C}$, but for $33 \%$ of the time it was above $15^{\circ} \mathrm{C}$. There is a possibility that some

218 temperature dependent changes occurred in this DDGS sample. Walters and Choct (1998)

219 suggested that degradation of some non-starch polysaccharides during storage may be the

220 cause of the increased in AME of stored cereal samples. Hesselman et al. (1981) observed a

221 reduction of beta glucan content in stored barley. Endogenous enzyme activity has been

222 suggested as the mechanism for these effects. However, it's unlikely that DDGS would have

223 any residual enzyme activity, although during the saccharification phase of DDGS production

224 cycle, alpha- and gluco- amylase enzymes are added to the mash in order to remove any

225 residual glucose residue (Smith et al., 2006).

226 In conclusion, the results of this experiment have shown that there can be changes in the

227 metabolisable energy of wheat DDGS during storage at ambient temperatures. The study has

228 been performed in a relatively cool climate with no extremes of temperature but these

229 conditions evidently can give a small improvement in the energy availability of DDGS. In

230 general, there were no serious effects of storage of DDGS on its feeding value to broiler

231 chickens. However, there is a large variability between different batches of DDGS thus

232 further studies that use multiple batches of DDGS may allow more definite conclusions.

233

234

235

236

237

238

239

\section{REFERENCES}

Adom, K.K. \& Liu, R.H. (2002) Antioxidant activity of grains. Journal of Agriculture \& Food Chemistry, 50: 6182-6187.

Allison, S.D. \& Treseder, K.K. (2008) Warming and drying suppress microbial activity and carbon cycling in boreal forest soils, Global Change Biology, 14: 2898-2909.

AOAC (2000) Official methods of analysis of the association of agricultural chemists, 17 th edition. Washington (US): Association of Official Analytical Chemists Inc.

Atapattu N., Wickramasinghe K.P., Serasinghe T., \& Gunarathne S.P. (2013) Effects of citric acid and butylated hydroxytoluene alone or in combination on prevention of rancidity of rice bran during storage, Journal of Rice Research, 1: 114

Berger, K.G. (1994) Practical measures to minimize rancidity in processing and storage. Pp. 68-83 in: Rancidity in Foods. 3rd edition. J.C. Allen and R.J. Hamilton, eds. Chapman and Hall. London, UK. 
Bolarinwa, O. A. \& Adeola, O. (2012) Energy value of wheat, barley, and wheat dried

254 distillers grains with solubles for broiler chickens determined using the regression method.

255 Poultry Science, 91: 1928-1935. polysaccharide-degrading enzymes increase the performance of broiler chickens fed wheat of low apparent metabolizable energy. Journal of Nutrition, 125: 485-492.

Choct, M. \& Hughes, R.J. (1997) The nutritive value of new season grains for poultry, in: CORBETT, J., CHOCT, M., NOLAN, J. \& ROWE, J. (Eds) Recent Advances in Animal Nutrition in Australia, pp. 146-150 (Armidale, Australia, University of New England).

Cozannet, P., Primot, Y., Gady, C., Métayer, J.P., Lessire, M., Skiba, F. \& Noblet, J. (2011) Standardised amino acid digestibility of wheat distillers' dried grains with solubles in forcefed cockerels. British Poultry Science, 52: 72-81.

Englyst, H.N., Quigley, M.E.\& Hudson., G. J. (1994) Determination of dietary fiber as nonstarch polysaccharides with gas-liquid chromatographic, high performance liquid chromatographic or spectrophotometric measurement of constituent sugars. Analyst, 119:1497-1509.

Englyst, K.N., Hudson, G.J. \& Englyst H.N. (2000) Starch analysis in food. Pages 42464262 in Encyclopaedia of Analytical Chemistry. R. A. Meyers, ed. John Wiley and Sons, Chichester, UK.

Finney, D.J. (1978) Statistical Method in Biological Assay. 3rd ed. Buckinghamshire. Charles Griffin \& Company Limited.

Hesselman, K., Elwinger, K., Nilsson, M. \& S. Thomke, S. (1981) The effects of $\beta$-glucanase supplementation, stage of ripeness and storage treatment of barley in diets fed to broiler chickens. Poultry Science, 60: 2664-2671.

Hill, F.W. \& Anderson, D.L. (1958) Comparison of metabolisable energy and productive energy determinations with growing chicks. Journal of Nutrition, 64:587-603.

Karadas, F., Pirgozliev, V., Rose, S.P., Dimitrov, D., Oduguwa O. \& Bravo D. (2014) Dietary essential oils improve the hepatic anti-oxidative status of broiler chickens. British Poultry Science, 55: 329-334

Karadas, F., Pirgozliev, V., Pappas, A.C., Acamovic, T. \& Bedford, M.R. (2010) Effects of different dietary phytase activities on the concentration of antioxidants in the liver of growing broilers. Journal of Animal Physiology and Animal Nutrition, 94: 519-526.

Pirgozliev, V., Rose, S.P. \& Kettlewell, P. (2006) Effect of ambient storage of wheat samples on their nutritive value for chickens. British Poultry Science, 47: 342-349.

Rasco, B.A. (1988) Stability of lipids in distilers' dried grain products made from soft white winter wheat. Cereal Chemistry, 65(3): 161-165 
Smith, T.C., Kindred, D.R., Brosnan, J.M., Weightman, R.M., Shepherd, M. \& Sylvester-

Bradley, R. (2006) Wheat as a feedstock for alcohol production. HGCA. UK.

Surai, P.F., Speake, B.K., Wood, N.A.R., Blount, J.D., Bortolotti, G.R., \& Sparks, N.H.C.

Walters, D.L. \& Choct, M. (1998) A simple method for the measurement of endogenous beta-glucanase activity in wheat. Page 204 in Proc. Australian Poultry Science Symposium, Sydney University Press, Sydney, NSW, Australia

Whiting, I.M., Pirgozliev, V., Rose, S.P., Wilson, J., Amerah, A.M., Ivanova, S.G., Staykova, distillers dried grains with solubles with and without exogenous enzymes for broiler

Figure. Average weekly temperature of the storage period of wheat DDGS (16 $6^{\text {th }}$ January 2014 to $9^{\text {th }}$ February 2015).

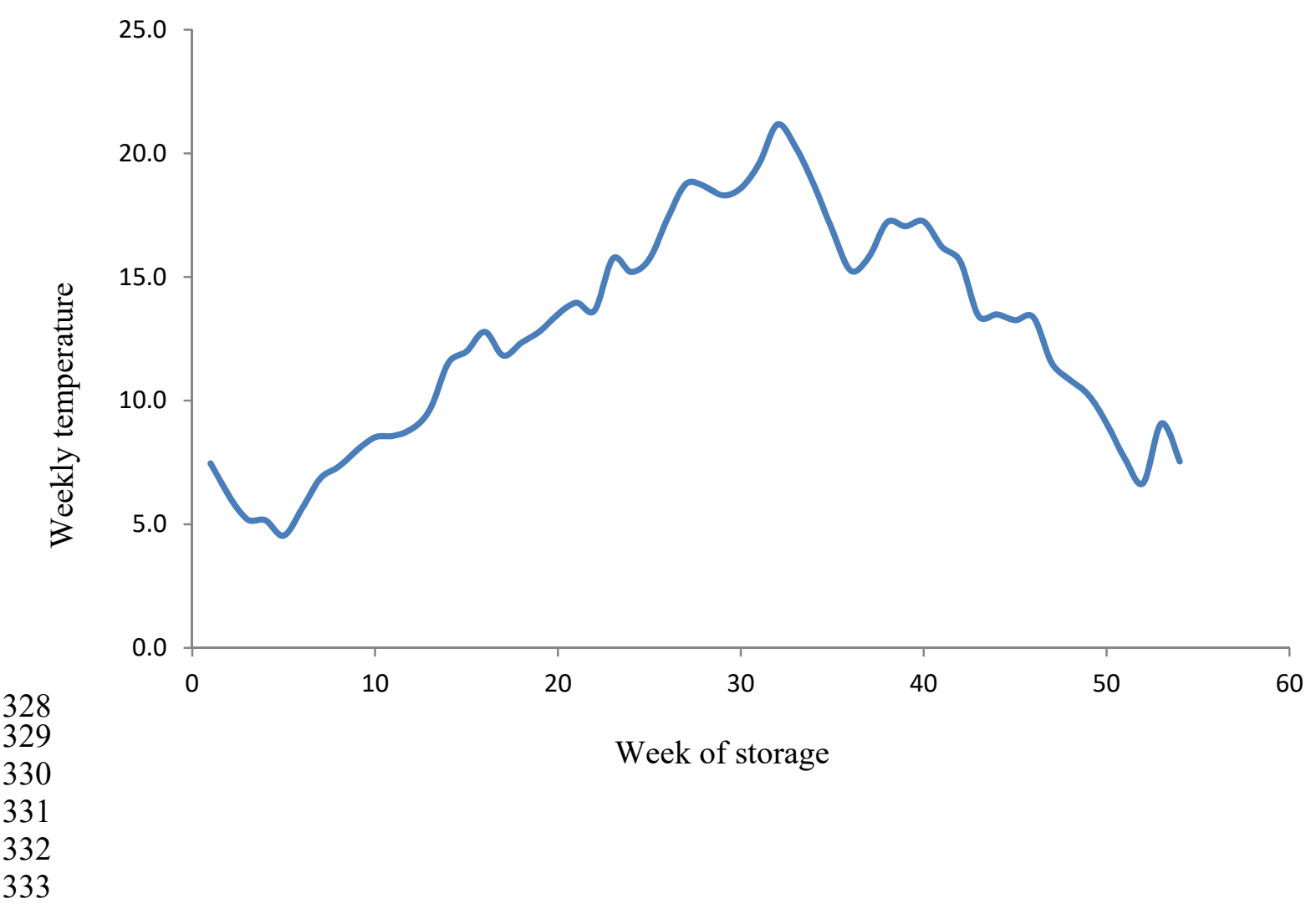


334

335

336

337 
341

342

343

344

345

346

347

348

349

350

351

352

353

354

355

356

357

358

359

360

361

362

Table 1. Experimental diet formulation

\begin{tabular}{lcc}
\hline Ingredient & Basal diet $\mathrm{g} / \mathrm{kg}$ & DDGS containing diet $\mathrm{g} / \mathrm{kg}$ \\
\hline & & \\
DDGS & - & 200 \\
Wheat & 670 & 536 \\
Soya bean meal $(\mathrm{CP}=48 \%)$ & 172 & 137.5 \\
Full fat Soya meal & 99 & 79 \\
Soya oil & 20 & 16 \\
Lysine & 3 & 2.4 \\
Methionine & 4.1 & 3.1 \\
Monocalcium phosphate & 11.4 & 9.4 \\
Limestone & 13.5 & 11 \\
Salt & 3 & 2.4 \\
Vitamin $/$ mineral premix ${ }^{1}$ & 4 & 3.2 \\
& & \\
Calculated composition & & \\
ME $(\mathrm{MJ} / \mathrm{kg})$ & 12.95 & 12.90 \\
Protein $(\mathrm{g} / \mathrm{kg})$ & 204.0 & 241.2 \\
Fat $(\mathrm{g} / \mathrm{kg})$ & 50.0 & 53.1 \\
Lysine $(\mathrm{g} / \mathrm{kg})$ & 13.0 & 10.4 \\
Met $+\mathrm{Cys}(\mathrm{g} / \mathrm{kg})$ & 9.4 & 7.5 \\
Calcium $(\mathrm{g} / \mathrm{kg})$ & 8.5 & 7.6 \\
Phosphorus av $(\mathrm{g} / \mathrm{kg})$ & 4.0 & 4.7 \\
Sodium $(\mathrm{g} / \mathrm{kg})$ & 1.7 & 1.3 \\
\hline
\end{tabular}

${ }^{1}$ The premix provided (units/kg diet): 12,000 IU retinol, 5,000 IU cholecalciferol, $34 \mathrm{mg} \alpha-$ tocopherol, $3 \mathrm{mg}$ menadione, $2 \mathrm{mg}$ thiamine, $7 \mathrm{mg}$ riboflavin, $5 \mathrm{mg}$ pyridoxine, $15 \mu \mathrm{g}$ cobalamin, $50 \mathrm{mg}$ nicotinic acid, $15 \mathrm{mg}$ pantothenic acid, $1 \mathrm{mg}$ folic acid, $200 \mu \mathrm{g}$ biotin, 80 $\mathrm{mg} \mathrm{Fe}$ as iron sulfate $(30 \%), 10 \mathrm{mg} \mathrm{Cu}$ as a copper sulfate $(25 \%), 100 \mathrm{mg} \mathrm{Mn}$ as manganous oxide (62\%), $80 \mathrm{mg} \mathrm{Zn}$ as zinc oxide (72\%), $1 \mathrm{mg}$ I as calcium iodate (52\%), $0.2 \mathrm{mg}$ Se as sodium selenite (4.5\%), and $0.5 \mathrm{mg}$ Mo as sodium molybdate (40\%). 
363 Table 2. Dry matter (DM), colour score (CS), peroxide value (PV), vitamin E, vitamin A, 364 coenzyme $Q_{10}$, and total starch (TS) contents of the DDGS samples stored under different 365 temperature conditions.

366

\begin{tabular}{lccccccc}
\hline $\begin{array}{l}\text { Storage conditions of } \\
\text { DDGS samples }\end{array}$ & $\begin{array}{c}\mathrm{DM} \\
(\mathrm{g} / \mathrm{kg})\end{array}$ & $\mathrm{CS}$ & $\begin{array}{c}\mathrm{PV} \\
(\mathrm{mEq} / \mathrm{kg})\end{array}$ & $\begin{array}{c}\text { vit E } \\
(\mu \mathrm{g} / \mathrm{g})\end{array}$ & $\begin{array}{c}\text { vit A } \\
(\mu \mathrm{g} / \mathrm{g})\end{array}$ & $\begin{array}{c}\mathrm{Q}_{10} \\
(\mu \mathrm{g} / \mathrm{g})\end{array}$ & $\begin{array}{c}\mathrm{TS} \\
(\mathrm{g} / \mathrm{kg} \mathrm{DM})\end{array}$ \\
\hline Before storage & 896 & 38.6 & $*$ & $*$ & $*$ & $*$ & 37.0 \\
$-20^{\circ} \mathrm{C}$ & 883 & 43.5 & 0.0 & 33.4 & 0.066 & 2.43 & 18.1 \\
$+4^{\circ} \mathrm{C}$ & 882 & 45.1 & 17.6 & 39.0 & 0.087 & 2.92 & 18.7 \\
$-20^{\circ} \mathrm{C}$ for $24 \mathrm{~h}$ then $+4^{\circ} \mathrm{C}$ & 880 & 40.6 & 18.2 & 37.6 & 0.084 & 2.77 & 11.9 \\
$+15^{\circ} \mathrm{C}$ & 878 & 43.9 & 16.9 & 41.0 & 0.075 & 3.19 & 9.1 \\
Ambient temperature & 819 & 40.0 & 18.2 & 35.3 & 0.047 & 2.92 & 9.8 \\
\hline
\end{tabular}

367

368

* Not determined before storage. 
370 Table 3. The effect of dietary DDGS samples stored at different temperature on daily feed intake (FI) presented on dry matter, weight gain (WG), feed conversion efficiency (FCE), liver weight, dietary $N$ corrected apparent metabolisable energy (AMEn), total tract dry matter retention (DMR), fat digestibility (FD) coefficients.

\begin{tabular}{lccccccc}
\hline $\begin{array}{l}\text { Storage conditions of DDGS } \\
\text { samples }\end{array}$ & $\begin{array}{c}\text { FI } \\
(\mathrm{g} / \mathrm{b} / \mathrm{d}\end{array}$ & $\begin{array}{c}\mathrm{WG} \\
(\mathrm{g} / \mathrm{b} / \mathrm{d})\end{array}$ & $\begin{array}{c}\text { FCE } \\
(\mathrm{g}: \mathrm{g})\end{array}$ & $\begin{array}{c}\text { Liver } \\
\text { weight } \\
(\mathrm{g})\end{array}$ & $\begin{array}{c}\text { AMEn } \\
(\mathrm{MJ} / \mathrm{kg} \mathrm{DM})\end{array}$ & $\begin{array}{c}\text { DMR } \\
\text { FD }\end{array}$ \\
\hline$-20^{\circ} \mathrm{C}$ & 42.0 & 28.4 & 0.678 & 17.2 & $10.71^{\mathrm{a}}$ & 0.441 & 0.754 \\
$+4^{\circ} \mathrm{C}$ & 43.2 & 29.5 & 0.688 & 20.6 & $10.76^{\mathrm{a}}$ & 0.458 & 0.709 \\
$-20^{\circ} \mathrm{C}$ for $24 \mathrm{~h}$ then $+4^{\circ} \mathrm{C}$ & 44.6 & 29.6 & 0.666 & 17.8 & $11.51^{\mathrm{ab}}$ & 0.499 & 0.813 \\
$+15^{\circ} \mathrm{C}$ & 44.4 & 29.9 & 0.673 & 17.4 & $10.89^{\mathrm{a}}$ & 0.452 & 0.721 \\
Ambient temperature & 45.6 & 30.6 & 0.673 & 19.0 & $12.13^{\mathrm{b}}$ & 0.448 & 0.795 \\
$\mathrm{SEM}$ & 1.622 & 1.217 & 0.0134 & 1.01 & 0.350 & 0.0224 & 0.0379 \\
$\mathrm{P}$ & 0.560 & 0.783 & 0.810 & 0.117 & 0.030 & 0.400 & 0.242 \\
\hline
\end{tabular}

375

376

377

378

379

380

381

382

383

384

385

386

387

388

389

390

391

392

393

394

395

396

397

398

399

400

401

402

403

404

405

406

407

408

409

410

The values for FI, WG and FCE are based on the average for 14 days feeding period from 7 to $21 \mathrm{~d}$ age. Dietary AME, DMR and FD were determined between 17 and $21 \mathrm{~d}$ of age. The values of AMEn, DMR and FD are for the DDGS samples as derived by substitution method explained in text.

There is a statistically significant difference between treatments when $\mathrm{P} \leq 0.05$. 
411 Table 4. The effect of dietary DDGS samples stored at different temperature on 412 concentration $(\mu \mathrm{g} / \mathrm{g})$ and total $(\mu \mathrm{g})$ hepatic vitamin A, vitamin E and coenzyme $Q_{10}$ when fed 413 to broilers for 14 days.

414

\begin{tabular}{lcccccc}
\hline Storage conditions of DDGS samples & $\begin{array}{c}\text { vit A } \\
(\mu \mathrm{g} / \mathrm{g})\end{array}$ & $\begin{array}{c}\text { vit } \mathrm{A} \\
(\mu \mathrm{g})\end{array}$ & $\begin{array}{c}\text { vit } \mathrm{E} \\
(\mu \mathrm{g} / \mathrm{g})\end{array}$ & $\begin{array}{c}\text { vit } \mathrm{E} \\
(\mu \mathrm{g})\end{array}$ & $\begin{array}{c}\mathrm{Q}_{10} \\
(\mu \mathrm{g} / \mathrm{g})\end{array}$ & $\begin{array}{c}\mathrm{Q}_{10} \\
(\mu \mathrm{g})\end{array}$ \\
\hline$-20^{\circ} \mathrm{C}$ & 1.4 & 24.4 & 9.9 & 164 & 16.3 & 277 \\
$+4^{\circ} \mathrm{C}$ & 1.2 & 26.4 & 7.43 & 157 & 15.8 & 323 \\
$-20^{\circ} \mathrm{C}$ for $24 \mathrm{~h}$ then $+4^{\circ} \mathrm{C}$ & 1.4 & 25.2 & 10.4 & 187 & 15.6 & 279 \\
$+15^{\circ} \mathrm{C}$ & 2.0 & 34.4 & 11.2 & 208 & 16.5 & 288 \\
$\mathrm{Ambient}$ temperature & 1.7 & 32.1 & 13.5 & 248 & 17.8 & 333 \\
$\mathrm{SEM}$ & 0.30 & 5.51 & 1.87 & 38.3 & 1.31 & 29 \\
$\mathrm{P}$ & 0.480 & 0.628 & 0.267 & 0.466 & 0.779 & 0.522 \\
\hline
\end{tabular}

415 There is a statistically significant difference between treatments when $\mathrm{P} \leq 0.05$. 